\title{
CREATION OF CAPABLE TERRITORIAL COMMUNITIES IN UKRAINE: ADVANTAGES, RISKS, DANGERS
}

\author{
'Pavlo OSTAPENKO, ²Oleksiy GNATIUK \\ 1,2Taras Shevchenko National University of Kyiv, Ukraine \\ 'ostapenkopavlo@gmail.com, ${ }^{2} a l e x g n a t 22 @ u k r . n e t$
}

\begin{abstract}
Contemporary Ukraine constitutes a scenery for creation of capable territorial communities within the framework of decentralization reform and reform of local government. In fact, we are witnesses of the large-scale administrative-territorial reform. However, public administration system would be inefficient if administrative-territorial structure is created without consideration of historical, geographical, socio-economic, cultural, ethnic, infrastructural peculiarities, and sooner or later it will have to be reformed again. The large majority of regional perspective plans virtually are not perfect. Moreover, only two regional perspective plans may be considered to be totally correct: in Luhansk and Donetsk regions, where only militarycivic administrations were responcible for plan development and adoption. As of 1 September 2016, Ukraine has created 184 consolidated local communities. However, analysis of perspective plans rises a question: how many recently created communities meet the requirements of perspective plans? How goes the process of territorial communities consolidation? Whether created communities meet official procedure? How quick and effective are changes that the system of administrative-territorial division currently survives? These questions the authors are trying to answer in this paper.
\end{abstract}

Key words: administrative-territorial division, consolidated territorial communities, resource capacity, fake consolidation.

DOI: https://doi.org/10.17721/2413-7154/2016.76.73-83

UDC: 911.3

\section{ФОРМУВАННЯ СПРОМОЖНИХ ТЕРИТОРІАЛЬНИХ ГРОМАД В УКРАЇНІ: ПЕРЕВАГИ, РИЗИКИ, ЗАГРОЗИ}

\author{
'ПавЛо ОСТАПЕНКО, '2ОлекСіЙ ГНАТЮК \\ 1,2Київський начіональний університет імені Тараса Шевченка, Україна \\ 'ostapenkopavlo@gmail.com, ${ }^{2} a l e x g n a t 22 @ u k r . n e t$
}

\begin{abstract}
Резюме: Станом на сьогодні, формування спроможних територіальних громад в Україні відбувається у рамках реформи децентралізації влади та місцевого самоврядування. Фактично, у рамках цієї реформи проходить реформа адміністративно-територіального устрою країни. Якщо система адміністративно-територіального устрою сформована без врахування історичних, географічних, демографічних, соціально-економічних, етнічних, культурних особливостей, характеристик інфраструктурного розвитку - система державного управління буде неефективною, і рано чи пізно ії доведеться знову реформувати. Аналіз сформованих в областях перспективних планів показав, що далеко не всі вони відповідають офіційній методиці. Більше того, на думку авторів статті, найбільш коректними $\epsilon$ лише два обласних перспективні плани - Луганської та Донецької областей, де відповідальними за формування та затвердження цих планів були лише обласні військово-цивільні адміністрації. Станом на 1 вересня 2016 року в Україні вже утворено 184 об'єднані територіальні громади. Аналізуючи перспективні плани, постає питання: скільки громад, які утворилися протягом двох років, відповідають перспективним планам? Яким чином відбувається процес об'єднання територіальних громад? Чи відповідають новоутворені об'єднані територіальні громади урядовій методиці? Як швидко та наскільки ефективно відбувається зміна системи адміністративно-територіального устрою України? На ці запитання ми спробуємо відповісти у даній статті.
\end{abstract}

Ключові слова: адміністративно-територіальний устрій, об'єднані територіальні громади, ресурсна спроможність, фейкове об'єднання громад.

DOI: https://doi.org/10.17721/2413-7154/2016.76.73-83

УДК: 911.3

Постановка проблеми. Станом на сьогодні формування спроможних територіальних громад в Україні відбувається у рамках реформи децентралізації влади та місцевого самоврядування. Але фактично у рамках цієї реформи паралельно проходить реформа адміністративно-територіального устрою країни. Практично, на даний час йде процес формування нових одиниць найнижчого рівня

(C) П. Остапенко, О. Гнатюк адміністративно-територіального устрою (АТУ) - об'єднаних територіальних громад - шляхом укрупнення існуючих одиниць найнижчого порядку - сільських рад. У даній статті представлена спроба проаналізувати, яким чином відбувається формування нових одиниць АТУ, і які наслідки може це спричинити?

Актуальність дослідження. Адміністративнотериторіальний устрій країни - це ï каркас, на який опираються всі інші галузі - містобудування. 
державне управління, економіка. Якщо система адміністративно-територіального устрою сформована без врахування історичних, географічних, соціальноекономічних, культурних особливостей розвитку території, демографічної, етнічної структури території, особливостей інфраструктурного розвитку - система державного управління буде неефективною, і рано чи пізно іiі прийдеться знову реформувати. Щоб такого не сталося, потрібно виважено, поступово, без зайвого поспіху проводити дану реформу. Аналіз спроможності новоутворених об'єднаних територіальних громад (ОТГ) показує, що лише 20-30 \% таких громад є самодостатніми та мають ресурси для подальшого розвитку. Утворення решти ОТГ не відповідає жодній методиці та законам територіального розвитку. Як суспільні географи, фахівці 3 територіального розвитку, у даній статті ми спробували детально проаналізувати, яким чином відбувається формування нових одиниць АТУ - об'єднаних територіальних громад у кожній області.

Виклад основного матеріалу. Станом на 1 вересня 2016 року кількість офіційно утворених ОТГ в Україні становила 184. 3 них 159 утворено у 2015 p., i лише вони повноцінно існують, оскільки мають спільний бюджет та вже сформували всі відповідні служби для реалізації власних та делегованих державною повноважень. Ще 25 ОТГ було утворено протягом 8 місяців 2016 року. Де-юре це вже цілком самостійні ОТГ, які провели перші місцеві вибори голови та депутатів і формують свої виконавчі органи. Проте, згідно чинного законодавства [2], бюджети таких ОТГ будуть виконуватись із нового бюджетного року, тобто з 2017 р. Також за експертними оцінками та власними оцінками джерел інформації [6], до кінця 2016 року в Україні планується утворення ще від 93 до 135 ОТГ. Таким чином, на кінець 2016 року в Україні буде утворено близько 300 ОТГ, що становить близько чверті від запланованої кількості проектних ОТГ [5].

Особливості проведення реформи АТУ. Як i в інших країнах Свропи, де реформа АТУ вже проведена, метою реформи у нашій країні стало [5]: створення адміністративних одиниць, здатних до самостійного економічного розвитку; забезпечення населення якісними послугами; створення умов для кадрового зростання в місцевому самоврядуванні.

Сучасна реформа АТУ має два принципові умови iii проведення: реформування повинне відбуватися шляхом добровільного об'єднання територіальних громад, а нові об'єднанні територіальні громади повинні бути спроможними. Ці умови підкріпляються новою законодавчою базою, яка була затверджена новою владою у 2014-2015 pр. Це:

1. Закон України «Про співробітництво територіальних громад» від 17.06.2014 № 1508-VII;

2. Закон України «Про добровільне об'єднання територіальних громад» від 05.02.2015 №157-19;

3. «Методика формування спроможних територіальних громад», затверджена Постановою КМУ від 08.04.2015 р., №214.

4. Закон України «Про внесення змін до
Бюджетного кодексу України щодо реформи міжбюджетних відносин» від 26.04.2015, N. 288-19;

5. Закон України «Про місцеві вибори» від 14.07.2015, №595-VIII;

6. Закон України «Про внесення змін до деяких законів України щодо організації проведення перших виборів депутатів місцевих рад та сільських, селищних, міських голів» від 04.09.2015 , №676-19.

Найбільш вагомими та основними нормативноправовими актами, у яких закладені основні норми проведення реформи АТУ, є Закон України «Про добровільне об'єднання громад» та Урядова «Методика формування спроможних територіальних громад».

Добровільне об'єднана повинне відбуватися на основі таких принципів:

1) повсюдності влади - у складі об'єднаної територіальної громади не може існувати іншої територіальної громади, яка має свій представницький орган місцевого самоврядування;

2) цілісності - територія об'єднаної територіальної громади має бути нерозривною, межі об'єднаної територіальної громади визначаються по зовнішніх межах юрисдикції рад територіальних громад, що об'єдналися; об'єднана територіальна громада має бути розташована в межах території Автономної Республіки Крим, однієї області;

3) економічної ефективності - при прийнятті рішень щодо добровільного об'єднання територіальних громад беруться до уваги історичні, природні, етнічні, культурні та інші чинники, що впливають на соціально-економічний розвиток об'єднаної територіальної громади;

4) відповідності - якість та доступність публічних послуг, що надаються в об'єднаній територіальній громаді, не можуть бути нижчими, ніж до об'єднання [2].

Але чи виконуються ці принципи на практиці?

Перспективні плани. Утворення ОТГ повинно відбуватися згідно до Закону «Про добровільне об'єднання територіальних громад» та низки інших законодавчих та нормативно-правових актів. Відповідно до цього закону, об'єднання територіальних громад повинно відбуватися добровільно. У цьому ж законів передбачена державна підтримка добровільного об'єднання територіальних громад. Держава здійснює інформаційно-просвітницьку, організаційну, методичну та фінансову підтримку добровільного об'єднання територіальних громад [2]. Також до форм державної підтримки відноситься розробка перспективних планів формування територій громад областей (далі - перспективний план). Перспективний план розробляється відповідною обласною державною адміністрацісю згідно 3 методикою формування спроможних територіальних громад i повинен охоплювати всю територію області. Методика формування спроможних територіальних громад розробляється центральним органом виконавчої влади Міністерством регіонального розвитку i будівництва, та затверджується Кабінетом Міністрів України [2†. 
Пояснення терміну «спроможна територіальна громада» наводиться в урядовій методиці формування спроможних територіальних громад - це територіальні громади сіл (селищ, міст), які в результаті добровільного об'єднання здатні самостійно або через відповідні органи місцевого самоврядування забезпечити належний рівень надання послуг, зокрема у сфері освіти, культури, охорони здоров'я, соціального захисту, житловокомунального господарства 3 урахуванням кадрових ресурсів, фінансового забезпечення та розвитку інфраструктури відповідної адміністративно-територіальної одиниці [3]. Однак, чіткого пояснення, що таке перспективний план і для чого він потрібен, ні у відповідному законі, ні в урядовій методиці немає.

Зрозуміло, що держава повинна забезпечувати формування та реалізацію державної політики у сфері територіальної організації влади, адміністративнотериторіального устрою, розвитку місцевого самоврядування i, таким чином, наявність таких перспективних планів необхідна, адже у випадку неналежного контролю добровільного об'єднання громад цей процес може призвести до появи великої кількості дотаційних та неспроможних ОТГ. Як це повинно працювати?
Відповідно до внесених змін до бюджетного кодексу, всі фінансові преференції, які передбачено для новоутворених ОТГ, вони зможуть отримати лише у тому випадку, якщо утворена ОТГ відповідатиме перспективному плану. Це головний запобіжник, який повинен запобігти поширенню великої кількості неспроможних, дотаційних та ресурсонезабезпечених ОТГ [8]. Фактично, це і є основна функція перспективного плану.

Проте, аналіз сформованих в областях перспективних планів показав, що далеко не всі вони ідеальні. Більше того, на думку авторів статті, найбільш коректними та такими, що відповідають дійсності, $€$ лише два обласних перспективних плани - Луганської та Донецької областей. Пояснення цьому є дуже простим - саме у цих областях були відсутні обласні ради, тому відповідальними за формування i затвердження цих планів були лише обласні військово-цивільні адміністрації (ВЦА). Тому, по-перше, керівництво ВЦА не дуже вникало у формування перспективних планів, оскільки військові мають інші задачі та підготовку, і всю роботу виконали експерти, по-друге відсутність схвалення цих двох перспективних планів обласними радами, які кругом лише заполітизовували процес, дозволило

Таблиия 1

Об'єднані територіальні громади в Україні

\begin{tabular}{|l|c|c|c|c|c|c|}
\hline Назва регіону України & $\begin{array}{c}\text { Кількість ОТГ } \\
\text { у перспекти- } \\
\text { вном плані, у } \\
2015 \text { р. }\end{array}$ & $\begin{array}{c}\text { Кількість } \\
\text { затвер- } \\
\text { дженних } \\
\text { ОТГ КМУ }\end{array}$ & $\begin{array}{c}\text { \% затвер- } \\
\text { джених } \\
\text { ОТГ КМУ }\end{array}$ & $\begin{array}{c}\text { Кількість } \\
\text { утворених } \\
\text { об'єднаних } \\
\text { громад у } \\
2015 \mathrm{p} .\end{array}$ & $\begin{array}{c}\text { Кількість } \\
\text { утворених } \\
\text { об'єднаних } \\
\text { громад у } \\
2016 \text { р.. }\end{array}$ & $\begin{array}{c}\text { Всього } \\
\text { утворено } \\
\text { ОТГ у 2015- } \\
\text { 2016 рр. }\end{array}$ \\
\hline Вінницька область & 106 & 29 & 27 & 2 & 2 & 4 \\
\hline Волинська область & 74 & 52 & 70 & 5 & 2 & 7 \\
\hline Дніпропетровська область & 89 & 74 & 83 & 15 & 1 & 16 \\
\hline Донецька область & 38 & 38 & 100 & 3 & & 3 \\
\hline Житомирська область & 59 & 38 & 63 & 9 & 1 & 10 \\
\hline Закарпатська область & 0 & 0 & 0 & 2 & & 2 \\
\hline Запорізька область & 69 & 51 & 74 & 6 & 1 & 7 \\
\hline Івано-Франківська область & 63 & 53 & 84 & 3 & 1 & 4 \\
\hline Київська область & 61 & 29 & 48 & 1 & 1 & 2 \\
\hline Кіровоградська область & 43 & 19 & 43 & 2 & 1 & 3 \\
\hline Луганська область & 24 & 24 & 100 & 2 & & 2 \\
\hline Львівська область & 160 & 90 & 56 & 15 & 1 & 16 \\
\hline Миколаївська область & 32 & 28 & 88 & 1 & & 1 \\
\hline Одеська область & 43 & 24 & 56 & 8 & & 8 \\
\hline Полтавська область & 57 & 45 & 79 & 12 & 2 & 14 \\
\hline Рівненська область & 45 & 33 & 73 & 5 & 9 & 14 \\
\hline Сумська область & 51 & 49 & 96 & 1 & & 1 \\
\hline Тернопільська область & 50 & 26 & 52 & 26 & & 26 \\
\hline Харківська область & 59 & 53 & 90 & & 3 & 3 \\
\hline Херсонська область & 43 & 41 & 95 & 1 & & 1 \\
\hline Хмельницька область & 54 & 40 & 74 & 22 & & 22 \\
\hline Черкаська область & 93 & 44 & 47 & 3 & & 3 \\
\hline Чернівецька область & 35 & 27 & 77 & 10 & & 10 \\
\hline Чернігівська область & 81 & 50 & 62 & 5 & & 5 \\
\hline Всього & $\mathbf{1 4 2 9}$ & $\mathbf{9 5 7}$ & - & $\mathbf{1 5 9}$ & $\mathbf{2 5}$ & $\mathbf{1 8 4}$ \\
\hline
\end{tabular}


швидко передати їх до Кабміну на затвердження. Як результат, обидва плани були затвердженні в повному обсязі, всі запропоновані громади були 100\% ресурсно спроможні для подальшого функціонування.

Аналіз поданих до Кабінету Міністрів України (КМУ) перспективних планів у 2015 році, показав, що загалом 23 області розробили такі плани, крім Закарпатської. Загальна кількість пропонованих обласними державними адміністраціями (ОДА) в перспективних планах громад (без Закарпатської області та АР Крим, тимчасово окупованих територій Донецької та Луганської областей) склала 1429, що загалом відповідає експертним прогнозам [8]. Однак, чисельність ОТГ у кожній області є різною, і ніяк не корелюється ні із площею, ні з населенням області. Найменшу кількість громад запропоновано утворити у Луганській області (не враховуючи тимчасово окуповані території) - 24 ОТГ. Найбільшу кількість ОТГ запропоновано утворити у Львівській області - 160. Різниця між областями становить 6,5 разів! Середня кількість ОТГ по областям становить 60 .

Більш детальний аналіз кожного перспективного плану показав, що практично всі вони, крім перспективних планів Донецької та Луганської областей, про які вже згадувалося раніше, не охоплюють усієї території області, що фактично порушує п.1 ст. 11 Закону України «Про добровільне об’єднання територіальних громад» [2]. Тобто, ОДА пішли іншим шляхом - у перспективних планах вони подавали лише ті ОТГ, які були на стадії утворення, або були погоджені із районною та місцевими владами, не враховуючи урядової методики, державних та регіональних інтересів. Таким чином, в кожній області залишились певні «сірі плями», на території яких поки відсутній офіційний варіант будь-якого об'єднання. Тому, якщо враховувати цей фактор, кількість ОТГ, які можуть бути утворені у областях, буде більшим, ніж пропонується сучасними перспективними планами. Загалом, при дотриманні такої політики, кількість ОТГ по країні, враховуючи «сірі плями», що не враховані у перспективних планах, може досягти до 2-2,5 тис., що значно перевищує експертні прогнози [4, 8].

Однак, потрібно враховувати той факт, що не всі перспективні плани були погоджені КМУ у повному обсязі. Загалом, КМУ погоджено та визнано спроможними близько $66 \%$ запропонованих у перспективних планах ОТГ - 957. Водночас, КМУ дав розпорядження продовжити розробку перспективних планів стосовно територій «сірих плям». Внесення змін до перспективних планів в областях триває i досі, не зважаючи на те, що вже 25 ОТГ було утворено у 2016 році. Отже, підбиваючи підсумок, можна стверджувати, що розробка перспективних планів необхідна для:

1. Належної реалізації державної політики у сфері територіальної організації влади та адміністративно-територіального устрою;

2. Попередження формування дотаційних та неспроможних («фейкових») територіальних громад;

3. стимулювання ОТГ, які утворилися поза перспективним планом, до подальшого об'єднання та утворення спроможних територіальних громад.

Важливий також той факт, що в Україні нині чинний закон «Про добровільне об'єднання територіальних громад», до його прийняття у Верховній Раді мав назву «Про право територіальних громад на об'єднання». В цьому законі не передбачалось проведення виборів органів місцевого самоврядування об'єднаної громади відразу після такого об'єднання, а створювались об'єднання органи до чергових виборів для м'якого перехідного періоду. Однак, ця норма не знайшла підтримки, і в ухваленому законі уже такий перехідний період був відсутній [5].

Варіанти добровільного об’сднання територіальних громад. Аналізуючи перспективні плани, постає інше питання, скільки ж ОТГ, які утворилися протягом двох років відповідає перспективним планам? Зрозуміло, що і самі перспективні плани далеко не ідеальні, але вони $\epsilon$ єдиною основою на яку потрібно опиратися проводячи добровільне об'єднання територіальних громад. Оскільки, як уже зазначалося раніше, від відповідності чи невідповідності перспективному плану буде залежати фінансування чи його відсутність для ОТГ [7].

Але, як показує практика, такий метод стримування поширення великої кількості неспроможних, «фейкових» ОТГ не застосовується. Як це відбувається? Коли ОТГ, яка, згідно до Закону [2], отримала позитивний висновок від ОДА стосовно відповідності Конституції та законам України щодо добровільного об'єднання, звертається через ОДА до ЦВК про призначення перших місцевих виборів голови та депутатів ОТГ, ОДА автоматично вносить правки до перспективного плану, і подає на затвердження до обласної ради вже змінений, а не початковий варіант перспективного плану. Обласна рада погоджує перспективний план i передає на затвердження до КМУ, який, за рекомендаціями профільного міністерства, усупереч власній Методиці формування спроможних територіальних громад затверджує такий перспективний план.

Затвердження КМУ перспективного плану дає підставу Мінфіну включити всі ОТГ, які погоджені у перспективному плані та у яких вже пройшли перші місцеві вибори, у прямі міжбюджетні відносини. Ось це і $€$ фактичним «народженням» нової фінансово самостійної одиниці АТУ - об’єднаної територіальної громади.

Такий процес затвердження усіх ОТГ, які були готові провести перші місцеві вибори у жовтні 2015 року, відбувся в усіх областях, де були затверджені таким чином перспективні плани. Це було зроблено лише задля однієї мети - позиціонування реформи децентралізації влади як такої, що вже розпочата, i яку неможливо зупинити. Але виникає інше питання, чи всі такі ОТГ реально є спроможними?

Географія новоутворених ОТГ. Найбільшу кількість ОТГ утворено у Тернопільській області 26 , що становить 27,7\% від території області, у яких проживає 228,2 тис. (21,3 \% населення області). Але 


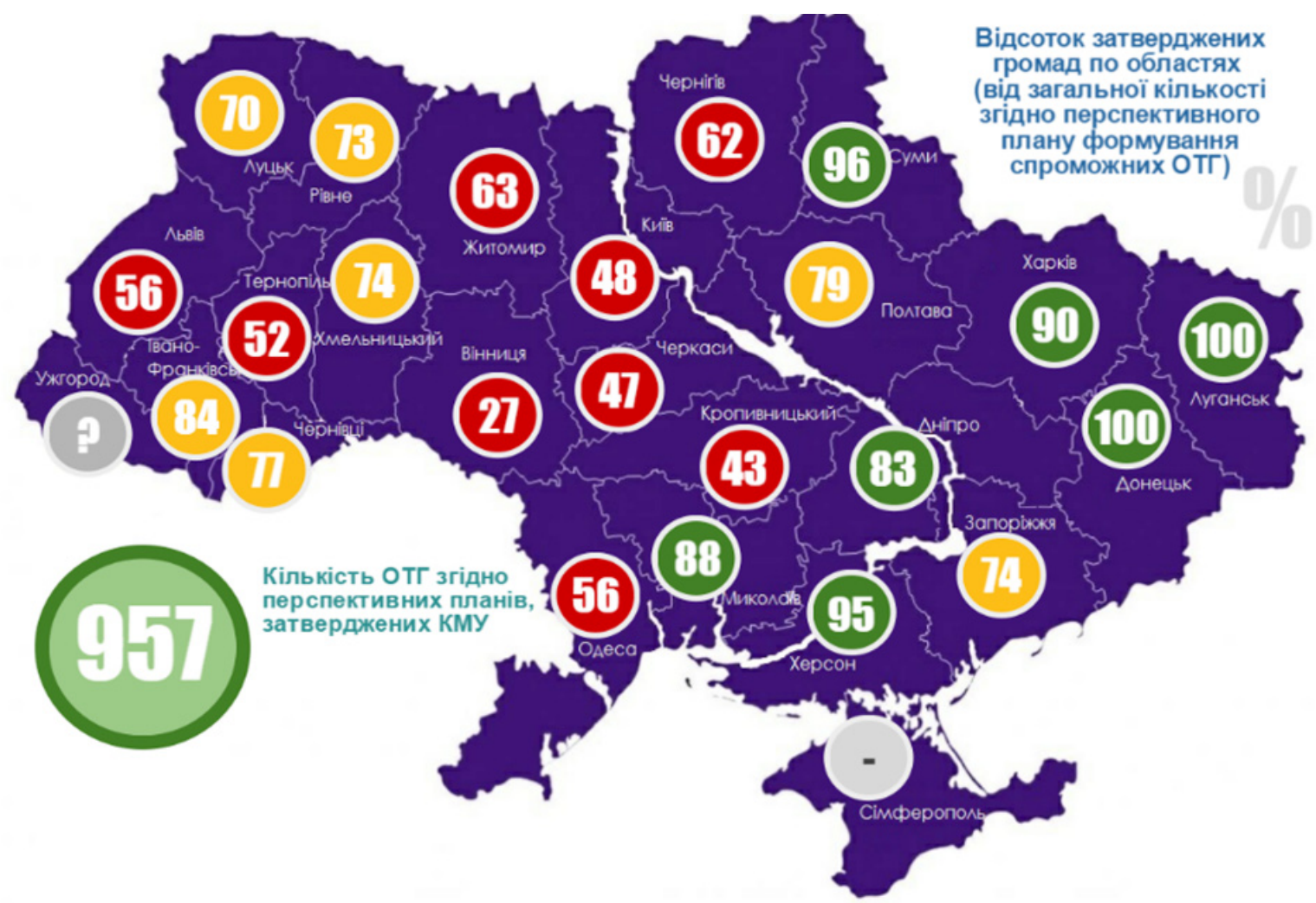

Рис. 1. Кількість об'єднаних територіальних громад відповідно до запропонованих перспективних планів формування територій громад областей України (2015).

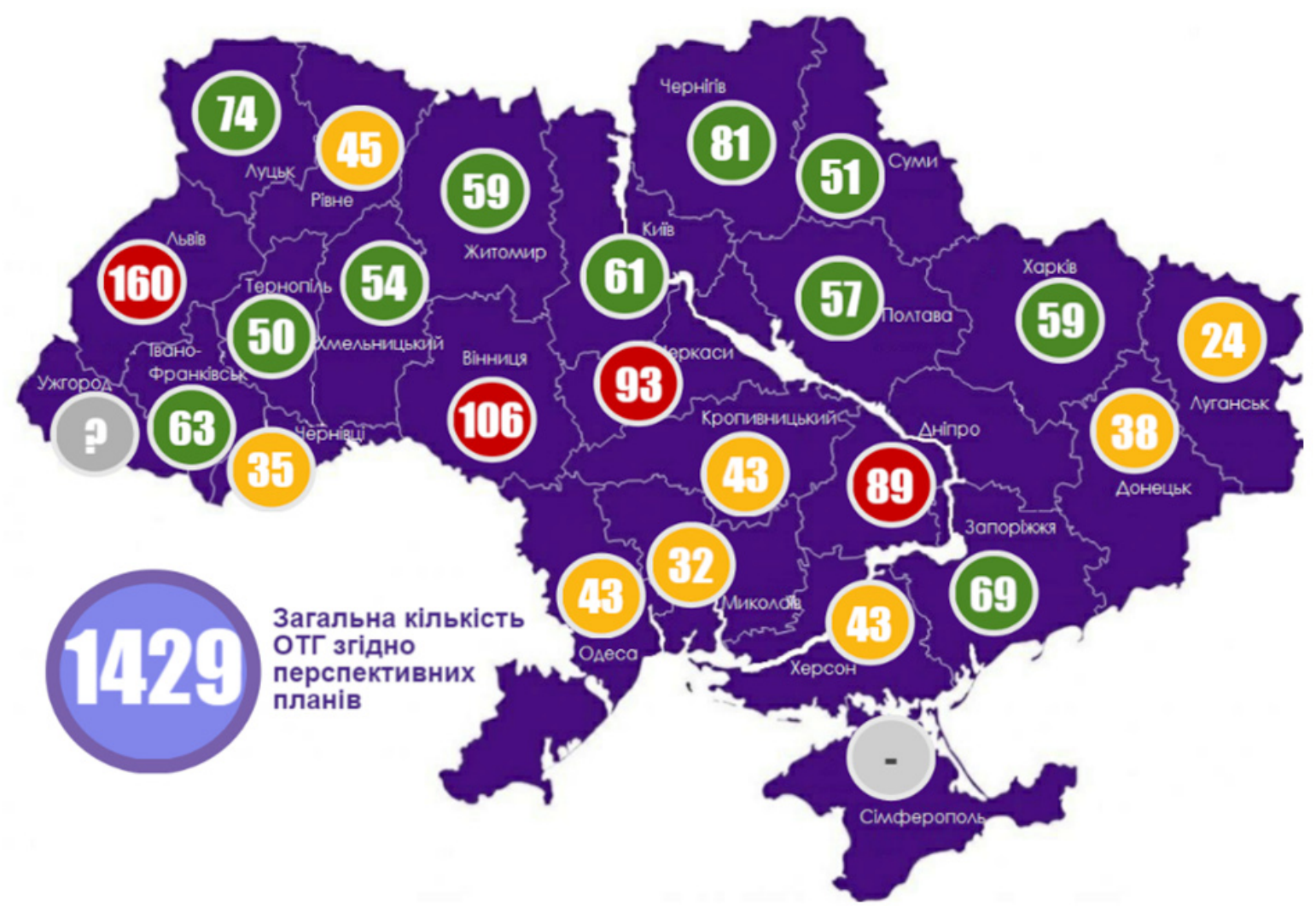

Рис. 2. Відсоток об'єднаних територіальних громад по областях України, які затвердив КМУ відповідно до запропонованих перспективних планів формування територій громад областей України (2015). 
Доходи бюджету на 1 особу по ОТГ

\section{Таблиия 2}

\begin{tabular}{|l|c|c|}
\hline \multicolumn{1}{|c|}{ Показник } & Кількість ОТГ & Частка, $\%$ \\
\hline більше 2,8 & 8 & 5,0 \\
\hline $2,1-2,8$ тис. грн. & 10 & 6,3 \\
\hline $1,4-2,1$ тис. грн. & 36 & 22,6 \\
\hline 0,7-1,4 тис. грн. & 61 & 38,4 \\
\hline менше 0,7 тис. грн. & 44 & 27,7 \\
\hline Всього & 159 & 100,0 \\
\hline
\end{tabular}

Таблиия 3

Частка видатків на утримання службовців ОТГ (від загальної суми бюджету ОТГ без врахування субвенцій)

Питома вага (часта) видатків розвитку у власних ресурсах ОТГ (без субвенцій)

\begin{tabular}{|l|c|c|}
\hline \multicolumn{1}{|c|}{ Показник } & Кількість ОТГ & Частка, $\%$ \\
\hline більше $40 \%$ & 4 & 2,5 \\
\hline $20,01-40,00 \%$ & 24 & 15,1 \\
\hline $10,01-20,00 \%$ & 27 & 17,0 \\
\hline до $10 \%$ & 51 & 32,1 \\
\hline Бюджети розвитку відсутні & 53 & 33,3 \\
\hline Всього & 159 & 100,0 \\
\hline
\end{tabular}

Табличя 4

Дотаційність бюджетів ОТГ

\begin{tabular}{|l|c|c|}
\hline \multicolumn{1}{|c|}{ Показник } & Кількість ОТГ & Частка, $\%$ \\
\hline більше $50 \%$ & 22 & 13,8 \\
\hline $30,01-50,00 \%$ & 30 & 18,9 \\
\hline $10,01-30,00 \%$ & 52 & 32,7 \\
\hline до $10 \%$ & 21 & 13,2 \\
\hline не дотаційні & 34 & 21,4 \\
\hline Всього & 159 & 100,0 \\
\hline
\end{tabular}

Таблиия 5

Видатки на 1 учня по ОТГ, тис. грн. / рік

\begin{tabular}{|l|c|c|}
\hline \multicolumn{1}{|c|}{ Показник } & Кількість ОТГ & Частка, $\%$ \\
\hline менше 9,3 & 10 & 6,3 \\
\hline $9,3-14$ & 57 & 35,8 \\
\hline $14-18,6$ & 74 & 46,5 \\
\hline більше 18,6 & 18 & 11,3 \\
\hline Всього & 159 & 100,0 \\
\hline
\end{tabular}

* 9,3 тис. грн. / рік - фінансовий норматив бюджетної забезпеченості на 1 учня у 2016 році

\begin{tabular}{|l|c|c|}
\hline \multicolumn{1}{|c|}{ Показник } & Кількість ОТГ & Частка, $\%$ \\
\hline до $10 \%$ & 3 & 1,9 \\
\hline $11 \%-20 \%$ & 47 & 29,6 \\
\hline $21 \%-30 \%$ & 50 & 31,4 \\
\hline $31 \%-40 \%$ & 38 & 23,9 \\
\hline $41 \%-50 \%$ & 17 & 10,7 \\
\hline більше $50 \%$ & 4 & 2,5 \\
\hline Всього & 159 & 100,0 \\
\hline
\end{tabular}

Таблиия 7

Показник забезпечення ОТГ службовцями (кількість жителів що припадає на одного службовця ОТГ)

\begin{tabular}{|l|c|c|}
\hline \multicolumn{1}{|c|}{ Показник } & Кількість ОТГ & Частка, $\%$ \\
\hline більше 1000 осіб & 1 & 0,6 \\
\hline $501-1000$ осіб & 4 & 2,5 \\
\hline $301-500$ осіб & 30 & 18,9 \\
\hline $101-300$ осіб & 114 & 71,7 \\
\hline до 100 осіб & 10 & 6,3 \\
\hline Всього & 159 & 100,0 \\
\hline
\end{tabular}

Таблиия 8

Обсяг субвенцій з державного бюджету на формування інфраструктури ОТГ, тис. грн.

\begin{tabular}{|l|c|c|}
\hline \multicolumn{1}{|c|}{ Показник } & $\begin{array}{c}\text { Кількість } \\
\text { ОТГ }\end{array}$ & Частка, $\%$ \\
\hline $\begin{array}{l}\text { більше 20,00 млн. } \\
\text { грн. }\end{array}$ & 4 & 2,5 \\
\hline 10,01-20,00 млн. грн. & 17 & 10,7 \\
\hline 5,01-10,00 млн. грн. & 60 & 37,7 \\
\hline 2,01-5,00 млн. грн. & 65 & 40,9 \\
\hline 1,01-2,00 млн. грн. & 11 & 6,9 \\
\hline до 1 млн. грн. & 2 & 1,3 \\
\hline Всього & 159 & 100,0 \\
\hline
\end{tabular}

Таблиия 9

Частка субвенції на формування інфраструктури ОТГ відносно до дохідної частини бюджету ОТГ

\begin{tabular}{|l|c|c|}
\hline \multicolumn{1}{|c|}{ Показник } & Кількість ОТГ & Частка, $\%$ \\
\hline більше $200 \%$ & 15 & 9,4 \\
\hline $100-200 \%$ & 46 & 28,9 \\
\hline $50-100 \%$ & 58 & 36,5 \\
\hline $20-50 \%$ & 24 & 15,1 \\
\hline до $20 \%$ & 16 & 10,1 \\
\hline Всього & 159 & 100,0 \\
\hline
\end{tabular}


найбільшу площу від загальної площі області ОТГ займають у Хмельницькій області - 35,9\%. У цій же області проживає найбільша частка населення в ОТГ - майже 300 тис. осіб, що становить $23 \%$ від загальної чисельності області. Загалом, у цій області творено 22 ОТГ. Лідерами в утворені нових одиниць АТУ - об'єднаних територіальних громад - $\epsilon$ також Дніпропетровська (16), Львівська (16), Рівненська (14), Полтавська (14), Чернівецька (10), Житомирська (10) області.

Якщо розглядати типізацію новоутворених ОТГ за центрами їх утворення, то найбільшу кількість становлять ОТГ, центрами яких стали сільські населені пункти - 104 ОТГ, 53 ОТГ утворено 3 центром у селищах та 27 ОТГ із центром із містах.

Демографічна структура новоутворених ОТГ. На даний час найбільшою ОТГ за чисельністю населення є Лиманська ОТГ Донецької області (43,0 тис. осіб). Ще 5 ОТГ мають чисельність населення більше 30 тис. - Дунаївецька ОТГ Хмельницької області (38,2 тис. осіб), Волочиська ОТГ Тернопільської області (33,1 тис. осіб), Полонська ОТГ Хмельницької області (33,0 тис. осіб), Балтська ОТГ Одеської області (32,9 тис. осіб), Теребовлянська ОТГ Тернопільської області (30,0 тис. осіб). Ще 38 ОТГ мають населення від 10 до 20 тис. осіб. Решта ОТГ мають населення менше 10 тис. осіб, при чому близько 70 ОТГ мають населення менше 5 тис. осіб. Загалом, найменшою ОТГ $є$ Макіївська ОТГ Чернігівської області (1,3 тис.осіб). Таким чином чисельність населення найбільшої ОТГ у 27 разів перевищує чисельність найменшої ОТГ. Середня чисельність новоутворених ОТГ в Україні становить 8,7 тис. осіб. Частка міського населення становить $65 \%$.

Територіальна структура новоутворених ОТГ. Найбільші за чисельністю ОТГ мають об'єднують у своєму складі і найбільшу кількість населених пунктів. Але найбільша за чисельністю Лиманська ОТГ займає лише 9 місце, маючи у своєму складі 40 населених пунктів. Проведений аналіз виявив, що на територіальну структуру ОТГ впливає географічне положення ОТГ. Так, найбільші ОТГ за кількісним складом Народницька ОТГ Житомирської області (66 населених пунктів), Шишацька ОТГ Полтавської області (63 населені пункти), Новоушицька ОТГ Хмельницької області (53 населені пункти). Загалом, кількість ОТГ, що мають у своєму складі більше 10 населених пунктів, становить близько 80. Решта 100 ОТГ у своєму складі мають до 10 населених пунктів, при чому 5 ОТГ у своєму складі мають лише 2 населених пункти, 8 ОТГ по 3 населених пункти - це Мерефянська міська (Харківська), Калинівська міська (Вінницька), Зеленодольська міська (Дніпропетровська), Тячівська міська (Закарпатська), Пирятинська міська (Полтавська), Печеніжинська селищна (Івано-Франківська), Біляївськаміська (Одеська), Маловисківськаміслька

(Кіровоградська), Калитянська селищна (Київська), Бобринецька міська (Кіровоградська), Сокринська міська
(Чернівецька),

Великокучурівська

сільська (Чернівецька), Мамалигівська сільська (Чернівецька). Ще 24 ОТГ включають по 4-5 населених пункти. Показники площ новостворених ОТГ є також строкатими. Різниця між найбільшою за площею ОТГ (Народницька ОТГ Житомирської

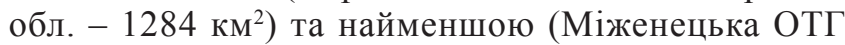
Львівської обл. - 8,8 км²) становить майже 146 разів! Загалом, кількість ОТГ що мають площу від 1200 до 500 км², яка є найбільш оптимальною згідно усіх методик, становить не більше 15, це близько 10\% від загальної кількості ОТГ! Ще 20 ОТГ мають площу від 300 до 500 км², 76 ОТГ

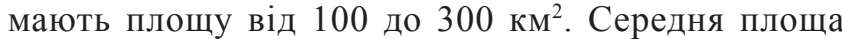
ОТГ становить близько 225 км². $^{2}$

Фінансова спроможність. Аналіз фінансових показників та визначення фінансової спроможності новостворених ОТГ проводився згідно даних Мінрегіону [1] та включав у себе показники дохідності на одну особу у 2016 р, показники дотаційності бюджетів новостворених ОТГ, показників питомої ваги видатків розвитку у власних ресурсах ОТГ.

Першим показником, який визначає фінансову спроможність ОТГ є дохідність на одну особу. Цей показник досліджено за 2016 рік. Найбільше доходів на одного жителя мають Вербківська ОТГ Дніпропетровської області (7,2 тис. грн./1 особу), Богданівська ОТГ Дніпропетровської області (6,9 тис. грн./1 особу), Байковецька ОТГ Тернопільської області (5,6 тис. грн./1 особу), Ювілейна ОТГ Дніпропетровської області (4,9 тис. грн./1 особу), Пришибська ОТГ Полтавської області (4,2 тис. грн./1 особу). Ще 14 ОТГ мають такий показник у межах від 2 до 3 тис. грн. /1 особу. Загалом, 91 ОТГ iз 159 мають показник дохідності на 1 особу більше 1 тис. грн. Решта 58 ОТГ мають нижчі показники дохідності. Середній показник дохідності бюджету на 1 особу становить - 1,3 тис. грн., що фактично відповідає середньо державному показнику - 1,4 тис. грн. [1].

Якщо розглядати бюджети новоутворених ОТГ у абсолютних показниках, то їх цифри також вражаючі. Наприклад, 3 ОТГ (Вільшаницька та Міженецька Львівської обл. та Лопушненська Тернопільської обл.) мають бюджети менше 1 млн. грн., ще 36 ОТГ мають бюджети у розмірі від 1 до 3 млн. грн., і лише 1/3 бюджетів ОТГ мають розміри більше 10 млн. грн. Найбільший бюджет має найбільша за чисельністю населення Лиманська ОТГ Донецької області - 74 млн. грн. [1]. Середній показник дохідної частини усіх ОТГ становить 11,7 млн. грн.

Наявність бюджетів розвитку - другий показник, який характеризує фінансову спроможність новоутворених ОТГ. Однак, обсяг коштів, які ОТГ може використати для свого розвитку, визначається передусім часткою бюджету розвитку у загальному бюджеті ОТГ. Це основний критерій, за яким можна провести аналіз перспектив розвитку територій ОТГ. За показником питомої ваги видатків розвитку у власних 
ресурсах лідерами здебільшого $є$ сільські ОТГ. Найбільші частки бюджету розвитку закладено Новоолександрівській ОТГ Дніпропетровської області (майже 60\%), Розсошанській ОТГ Хмельницької області (майже 50\%), Калинівській ОТГ Вінницької області (47,5%). Середній показник бюджету розвитку серед ОТГ становить 2,5 млн. грн. Загалом, 106 бюджетів ОТГ із 159 (2/3) мають кошти, передбачені на капітальні видатки (бюджети розвитку), 1/3 новоутворених ОТГ таких коштів у своїх бюджетах не передбачили. Це означає, що такі ОТГ вже не $є$ фінансово спроможними.

Однак, найбільш репрезентативним показником фінансової спроможності ОТГ дотаційність їх бюджетів. Він показує реальний обсяг наповнення бюджетів новостворених ОТГ. Згідно даних Міністерства регіонального розвитку, будівництва та житлово-комунального господарства України [1] лише 22\% ОТГ (34) мають недотаційний бюджет. Серед дотаційних бюджетів (125) 40\% ОТГ (50) мають відсоток дотаційності від 0,5\% до 20\%, ще 40\% ОТГ (50) мають відсоток дотаційності від 20\% до 50\%, і $20 \%$ ОТГ (25) мають відсоток дотаційності більше 50\%. Найбільш дотаційною є Золотопотіцька ОТГ Тернопільської області - на 70\%. Середня дотаційність бюджетів ОТГ становить $27,6 \%$.

Ресурсна спроможність території визначається за великим набором показників, до якого входять показники природно-ресурсного потенціалу, інфраструктурного забезпечення, працересурсного потенціалу території. Мми спробували зробити аналіз ресурсної спроможності території новостворених ОТГ за наявним набором відомих показників. До них належать: показники розвитку освітньої інфраструктури - видатки на 1 учня, показники кадрового забезпечення території - кількість жителів що припадає на одного службовця ОТГ, частка витрат на утримання службовців ОТГ, показники розвитку інфраструктури ОТГ - обсяг субвенцій 3 державного бюджету, що передбачений на формування інфраструктури ОТГ.

Перший показник - видатки на навчання 1 учня у загальноосвітніх школах - показує рівень комплектності та модернізації середніх навчальних закладів, а також вартість навчання одного учня в ОТГ у порівнянні до середньодержавного фінансового нормативу бюджетної забезпеченості на 1 учня [1]. Особливість цього показника полягає в тому, що $з$ державного бюджету перераховується лише певна гранично допустима сума коштів на утримання закладів середньої освіти в ОТГ. Відповідно до бюджетних розрахунків у 2016 році гранично допустима сума на утримання 1 учня складала 9,3 тис. грн. / рік [1]. Якщо сума перевищує цей показник, ОТГ повинна сама, за рахунок власних коштів, покривати таку різницю, що, звісно, є додатковим тягарем у бюджеті громади. Якщо проаналізувати цей показник у розрізі усіх ОТГ (159), ми отримаємо такі результати: лише
10 ОТГ (6\%) (6 міських та 4 селищних) мають витрати на 1 учня менші до середньодержавних, у решти 149 ОТГ (94\%) цей показник перевищує його. Найбільші витрати на утримання 1 учня (22,7 тис. грн./ рік) припадає на Березівську ОТГ Сумської області. Середній показник витрат 1 учня по усіх ОТГ - 14,9 тис. грн., що перевищує середньодержавний майже у 1,5 рази.

Другий проаналізований нами показник кадрове забезпечення територій ОТГ, оскільки близько 2/3 ОТГ було утворено навколо населених пунктів, які мали лише статус центрів сільських або селищних рад. Відповідно до цього, кадровий склад таких рад був невеликий і їх штатний розпис не містив повного переліку посад, які необхідні для роботи новоутворених ОТГ: фактично на ОТГ було передано основну частину державних повноважень, які до цього виконували районні державні адміністрації. Відповідно до цього усім ОТГ потрібно було у стислі терміни, з листопада по грудень 2015 року, сформувати нові штатні розписи та розпочати процес їх формування. Складність такого процесу також полягає у тому, що у сільській місцевості, де наразі за малого контролю утворюється велика кількість сільських ОТГ, фактично відсутні кваліфіковані трудові ресурси у належній кількості, які б змогли забезпечити реалізацію власних та державних повноважень в ОТГ та надання елементарних адміністративних послуг для населення ОТГ, що $\epsilon$ головною умовою реформи. Таким чином, чим менш кваліфіковані кадри будуть працювати в ОТГ, тим більшу кількість штатних одиниць потрібно буде створювати, оскільки більш кваліфіковані спеціалісти виконують більший об'єм роботи за меншу одиницю часу. Відповідно, у таких ОТГ буде спостерігатися більше навантаження на фонд оплати праці, і ситуація нічим не відрізнятиметься від існуючої системи АТУ, коли на рівні міських, селищних, сільських рад основна частка витрат місцевого бюджету витрачається на оплату праці адміністративного персоналу. Якщо проаналізувати частку витрат на утримання службовців в ОТГ, маємо наступні результати: лише $29 \%$ ОТГ витрачають на службовців до $20 \%$ свого бюджету; 5 ОТГ витрачають більше 50 \% на оплату праці своїх службовців.

Якщо аналізувати показник кількості жителів, яких обслуговує 1 службовець ОТГ, то в середньому найбільші показники мають міські ОТГ, де чисельність жителів висока, і фактично вже сформований штатний розпис. Тому у таких ОТГ кількість нових працівників майже не збільшилась, що не можна сказати про сільські та селищні ОТГ, де кількість нових працівників значно зросла. Найбільша кількість мешканців громади на одного працівника припадає у Зеленодольській ОТГ Дніпропетровської області - більше 1000. Високий показник (більше 500 осіб на 1 службовця) також мають ще 4 ОТГ - Калинівська ОТГ Вінницької області (892), Дунаєвецька (538) і Понінківська ОТГ (527) Хмельницької області та Великокучурівська 
ОТГ Чернівецької області (525). Однак, 10 ОТГ мають величину цього показника до 100 осіб, що в 10 разів менше найвищого показника.

Останній проаналізований показник, який характеризує розвиток інфраструктури ОТГ, $\epsilon$ обсяг субвенцій 3 державного бюджету, що передбачені на формування інфраструктури ОТГ (соціальної, транспортної, освітньої, медичної). Ми погоджуємось, що цей показник не зовсім точно характеризує сучасний стан інфраструктури ОТГ. Але інфраструктурне забезпечення більшості населених пунктів, окрім міст обласного значення, перебуває у вкрай занедбаному стані, тому можна вважати, що стан інфраструктури усіх нині утворених ОТГ є майже однаковим і залежить лише від типу населеного пункту. У містах він трохи кращих, у селищах на середньому рівні, у селах найгірший. Але чому саме на цьому показнику було зосереджено увагу? Він показує, які ОТГ отримають більше коштів на розвиток своєї інфраструктури, а які менше. Відповідно до цього, ті ОТГ, які зможуть отримати більшу кількість коштів, передбачених цією субвенцією, матимуть більше шансів на прискорений розвиток своєї інфраструктури вже зараз. Найбільші інфраструктурні субвенції, більше 20 млн. грн., передбачено для найбільший за площею та кількістю сільського населення ОТГ - Линанська ОТГ Донецбкої області (23,2 млн. грн.), Новоушицька ОТГ Хмельницької області (22,8 млн. грн.), Народницька ОТГ Житомирської області (21,7 млн. грн.). Найменший розмір цієї субвенції передбачено для Заводської ОТГ Полтавської області (366,8 тис. грн.) [1]. Розмір найбільшої субвенції перевищує розмір найменшої майже у 60 разів!

Дана субвенція є значною підтримкою держави.

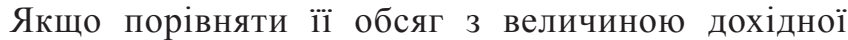
частини бюджетів ОТГ (власних ресурсів), то у деяких випадках інфраструктурна субвенція може перевищувати обсяг власне бюджету у декілька разів. Рекордсменами за цим показником є такі громади: Милявська ОТГ Рівненської області у 4,3 рази, Вільшанська ОТГ Львівської області - у 3,7 разів.

Таким чином, аналіз показників спроможності кожної з громад, які утворились у 2015 році (159 ОТГ), показав, що лише $1 / 5$ ОТГ $\epsilon$ фінансово спроможними та мають відповідну інфраструктуру.

Яким же чином проводиться утворення нових ОТГ? Загалом, нами зафіксовано 5 варіантів добровільного об'єднання територіальних громад, які розглянемо нижче на конкретному прикладі різних сценаріїв об'єднання територіальних громад в межах однієї і тієї самої території.

\section{Варіант 1. Об'єднання відповідає} перспективному плану. Якщо об'єднання територіальних громад відбувається згідно до затвердженого КМУ перспективного плану, ОТГ отримує прямі міжбюджетні відносини (стає окремою одиницею АТУ) та всі додаткові фінансові преференції, які передбачені у змінах до податкового кодексу. ОТГ формує свій виконавчий комітет, і фактично отримує такі самі повноваження, що і міста обласного значення.

Приклад: Медвинська ОТГ, затверджена як спроможна, згідно рішення КМУ №1206-р «Про затвердження перспективного плану формування територій громад у Київської області». Згідно до перспективного плану Медвинська сільська рада повинна об'єднатися із 5 сільськими радами та утворити Медвинську ОТГ із центром у селі Медвин.

Варіант 2. Об'єднання НЕ відповідає перспективному плану, але центр громади відповідає Перспективному плану. Якщо об'єднання територіальних громад відбувається не відповідно до затвердженого КМУ перспективного плану, але центр проектної ОТГ відповідає йому і всі територіальні громади проектної ОТГ також повинні входять до одної ОТГ згідно затвердженого КМУ перспективного плану. За таких обставин ОТГ вже не може отримувати прямі міжбюджетні відносини, але вона стає окремою одиницею АТУ. Де-факто відбувається укрупнення сільської (міської чи селищної) ради.

Приклад: Медвинська ОТГ, затверджена як спроможна, згідно рішення КМУ №1206-р «Про затвердження перспективного плану формування територій громад у Київської області». Згідно до перспективного плану до Медвинська сільська рада повинна об'єднатися із 5 сільськими радами та утворити Медвинську ОТГ із центром у селі Медвин. Однак, відповідно до рішень громадських обговорень, дві сільські ради відмовились добровільно об'єднуватись із Медвинською сільською радою та іншими сільськими радами відповідно до перспективного плану. Враховуючи це, інші 4 сільські ради об'єднались без цих сільських рад у сільську ОТГ з центром у селі Медвин. За таких умов решта сільських рад 3 великою ймовірністю все одно у майбутньому будуть приєднані до цієї ОТГ, оскільки це, поперше, передбачено перспективним планом, подруге, зумовлено існуючими факторами розвитку території. Таке приєднання можливе двома шляхами: добровільно - у межах існуючого законодавства, або примусово - після ухвалення Закону «Про адміністративно-територіальний устрій України».

Варіант 3. Об'єднання НЕ відповідає перспективному плану, центр громади НЕ відповідає Перспективному плану. При цьому всі територіальні громади, що вирішили об'єднатися, згідно до перспективного плану повинні входити до іншої ОТГ. За таких обставин ОТГ вже не може отримувати прямі міжбюджетні відносини, і дефакто така ОТГ просто стає окремою одиницею АТУ без отримання будь яких фінансових преференцій, які передбачені змінами до бюджетного кодексу у рамках фінансування ОТГ. У переважній більшості центрами таких проектних ОТГ є села, у яких знаходиться одне або декілька промислових чи аграрних підприємств. 
Приклад: Громада села Митаїв, як центр сільської ради, виявила бажання ініціювати об'єднання територіальних громад у Митаївську ОТГ 3 центром у селі Митаїв. За процедурою, яка передбачена у Законі [2], Митаївська сільська рада звернулась до усіх суміжних територіальних громад, та громад, які суміжні 3 ними. Проте, оскільки у сусідньому селі Медвин, згідно затвердженого КМУ перспективного плану, планується центр Медвинської ОТГ, лише одна сусідня сільська рада погодилась об'єднатися із Митаївською сільською радою та утворити Митївську ОТГ 3 центром у селі Митаїв. Пропозиції таких варіантів об’єднання $€$ найбільш поширеним. Однак, такі об’єднання якраз є найбільш «фейковими», оскільки подібні проектні та існуючі ОТГ ніколи не будуть в змозі реалізовувати власні та делеговані повноваження: їх територіальна структура та ресурсний потенціал недостатні для подальшого розвитку.

Варіант 4. Об'єднання НЕ відповідає перспективному плану, населені пункти із різних проектних громад, але центр проектноі ОТГ відповідає перспективному плану. За таких обставин ОТГ також не може отримати прямі міжбюджетні відносини.

Приклад: Громада села Круті Горби, як центру сільської ради, виявила бажання приєднатися до сусідньої проектної Медвинської ОТГ, утворення якої планується відповідно до затвердженого КМУ перспективного плану. Причиною такого рішення може бути позиція місцевих жителів, обгрунтована тим, що село територіально знаходиться ближче до центру проектної Медвинської ОТГ, інфраструктура проектної ОТГ є більш розвиненішою, село Медвин має свою дільничну лікарню, два дитячих садочки, велику модернізовану загальноосвітню школу та має кращі перспективи для розвитку. За таких обставин більш доречним буде внести зміни до перспективного плану та збільшити межі проектної Медвинської ОТГ, оскільки, такий варіант об'єднання не суперечить духу урядової методики формування спроможних територіальних громад.

Варіант 5. Об'єднання НЕ відповідає перспективному плану, населені пункти із різних проектних громад, центр проектної ОТГ НЕ відповідає перспективному плану.

Якщо об’єднання територіальних громад відбувається не відповідно до затвердженого КМУ перспективного плану, і центр проектної ОТГ також не відповідає йому. При цьому всі територіальні громади, що вирішили об'єднатися, згідно до перспективного плану повинні входити до різних ОТГ. Варіант є схожим до третього. За таких обставин ОТГ вже не може отримувати прямі міжбюджетні відносини, і де-факто така ОТГ просто стає окремою одиницею АТУ без отримання будь яких фінансових преференцій, які передбачені змінами до бюджетного кодексу у рамках фінансування ОТГ. У переважній більшості центри таких проектних ОТГ є села у яких знаходиться одне або декілька промислових чи аграрних підприємств.

Приклад: Громада села Митаїв, як центру сільської ради, виявила бажання ініціювати об'єднання територіальних громад у Митаївську ОТГ 3 центром у селі Митаїв. До цього села виявили бажання приєднатися дві сільські ради, одна 3 яких, згідно до перспективного плану, повинна була увійти, як і сама Митаївська сільська рада, до Медвинської ОТГ, а друга - до проектної Таращанської ОТГ. Пропозиції таких варіантів об'єднання є також поширеними. Однак, такі об'єднання є «фейковими», оскільки подібні проектні та існуючі ОТГ, через брак ресурсного та інфраструктурного забезпечення, ніколи не будуть в змозі реалізовувати власні та делеговані повноваження.

Висновки. Перспективні плани утворення об'єднаних територіальних громад далекі від ідеалу, але реальне утворення об'єднаних громад здебільшого відбувається всупереч будь-яким перспективним планам та врозріз 3 вимогами офіційної методики. Практична відсутність контролю з боку держави пояснюється прагненням державного керівництва досягти якомога більших кількісних результатів реформи, нехтуючи якістю нового адміністративно-територіального устрою. Лише близько 30 новоутворених ОТГ (15\%) мають більш-менш сформовану територіальну структуру та повністю відповідають урядовій Методиці формування спроможних територіальних громад. Решта громад де-факто перебувають на стадії формування, тому подальший їх розвиток може відбуватися за такими сценаріями: 1. приєднані нових сільських територій до існуючих міських та селищних ОТГ; 2. Приєднання ОТГ, утворених поблизу малих та середніх міст будуть, приєднані до громад, сформованих навколо цих міст; 3. до існуючих ОТГ, які утворені поза зоною впливу міст та селищ, приєднаються інші сільські населені пункти, які також не потрапляють в зону такого впливу.

\section{References:}

1. Decentralizaciâ. Miscevì bûdžeti 159 ob'êdnanih teritorìal'nih gromad. Fìnansovo-analiitični materìali [Decentralization. Local budget of 159 consolidated territorial communities. Financial analysis]. (Ed.: Я. M. Kâzûk), Kyiv: Ministry of Regional Development, Construction and Housing, 2016 (with support of the Swiss-Ukrainian Project DESPRO and Swedish-Ukrainian Project "Support for Decentralization in Ukraine");

2. Law of Ukraine "On voluntary consolidation of territorial communities" N 157-VIII dated 05.02.2015;

2. "Procedure for creation of capable territorial communities", approved by Resolution of the Cabinet of Ministers 
of Ukraine N 214 dated 08.04.2015;

3. Resolution of the Cabinet of Ministers of Ukraine N 214200 dated 16.03.2016;

4. TkačukA. Skandinavskij šlâh. Dosvìd reform administrativno-teritorìal'nogo ustroû ìmìscevogo samovrâduvannâ $v$ Daniï ta Šveciï [Scandinavian way. Experience of administrative division and local government reform in Denmark and Swedeen], Kyiv, 2015, 124 p. (In Ukrainian).

5. Website "Decentralization in Ukraine". Access mode: https://адмреф.сіаз.укр;

6. Website "Power decentralization reform in Ukraine". Access mode: https://decentralization.gov.ua.

7. Law of Ukraine "On Budget Code amendments related to reform of inter-budget relations" N 288-19 dated 26.04.2015.

8. Tkačuk A. Decentralizaciâ vladi: vid potrebi do realizacï [Power decentralization: from need to implementation]. Kyiv, 2013, 116 p. (In Ukrainian). 